\title{
Stereoselective aldol reaction catalyzed by a highly recyclable polystyrene supported substituted prolinamide catalyst
}

\author{
Michelangelo Gruttadauria,* Francesco Giacalone, Adriana Mossuto Marculescu, Anna \\ Maria Pia Salvo, and Renato Noto
}

Università di Palermo, Dipartimento di Chimica Organica “E. Paternò”, Viale delle Scienze, Pad. 17, 90128, Palermo, Italy

E-mail: $\underline{\text { mgrutt@unipa.it }}$

\section{This paper is dedicated to Professor Nicolò Vivona on the occasion of his $\mathbf{7 0}^{\text {th }}$ birthday}

\begin{abstract}
Polystyrene supported substituted prolinamide was used as catalyst in the aldol reaction between cyclohexanone or acetone and several substituted benzaldehydes in chloroform/water. This catalyst afforded aldol products in high yields and stereoselectivities, especially in the case of reactions performed with acetone. The catalyst was easily recovered by filtration and reused, after regeneration with formic acid, up to 22 times.
\end{abstract}

Keywords: organocatalysis, proline, aldol reaction, polystyrene

\section{Introduction}

Organocatalysis has received great attention in the last years. ${ }^{1}$ Organocatalysts are metal-free organic compounds of relatively low molecular weight and simple structure capable of promoting a reaction in substoichiometric amount. At the same time immobilization and recycling of organocatalysts has experenced a very good growth. ${ }^{2}$ Indeed, organocatalysts are usually used in substantial amount, in some cases up to $30 \mathrm{~mol} \%$. This is the main reason for the need of an efficient immobilization and recycling procedure. Moreover, immobilization of an organocatalyst may enhance its activity and stereoselectivity. Three different general approaches can be summarized for organocatalysts immobilization. Organocatalysts may be covalently supported: in this case organocatalysts have been covalently anchored to a soluble ${ }^{3}$ or insoluble ${ }^{4}$ support. Organocatalysts may be non-covalently supported: in this case several supports have been used in which the organocatalyst has been immobilized by using different techniques, adsorption, ${ }^{5}$ dissolution, ${ }^{6}$ inclusion $^{7}$ or linked by electrostatic interactions. ${ }^{8}$ Finally, biphasic catalysts can be used: in this case organocatalysts have been dissolved into ionic liquids and the 
product extracted using an immiscible solvent. ${ }^{9}$ Also, ionic liquid-anchored organocatalysts have been employed. ${ }^{10}$

Recently, paramount interest has been devoted to L-proline. ${ }^{11}$ Such amino acid can be regarded as the simplest "enzyme" and, in addition to Hajos-Parrish-Eder-Sauer-Wiechert reaction $^{12}$ and aldol reaction, ${ }^{13}$ it has been successfully applied to many other reactions. ${ }^{14}$ In addition to L-proline, many its derivatives, such as substituted prolinamides or pyrrolidines, have been investigated as useful organocatalysts in order to reach higher activities and stereoselectivities. $^{14}$ Synthesis of L-proline derivatives has also allowed new experimental procedures such as reaction performed in the presence of water. ${ }^{15}$ This approach has given higher stereoselectivities compared to the reactions carried out in organic solvents. A drawback of proline immobilization could be its high cost compared to the native proline. However, immobilization of proline has given, in some cases, catalysts which have shown higher stereoselectivities. ${ }^{4 a, 16}$ Moreover, immobilization of more expensive organocatalysts, and hence their recovery and re-use, could be of higher value, from an economical point of view, so increasing the greenness of the process.

Several substituted prolinamides have been reported as useful catalysts for the aldol reaction both in organic solvents ${ }^{17}$ and in aqueous conditions. ${ }^{18}$ Among the examples reported in the literature, catalysts $\mathbf{1}$ and $\mathbf{2}$ have given aldol products in excellent enantio- and diastereoselectivity. ${ }^{18 \mathrm{~b}}$
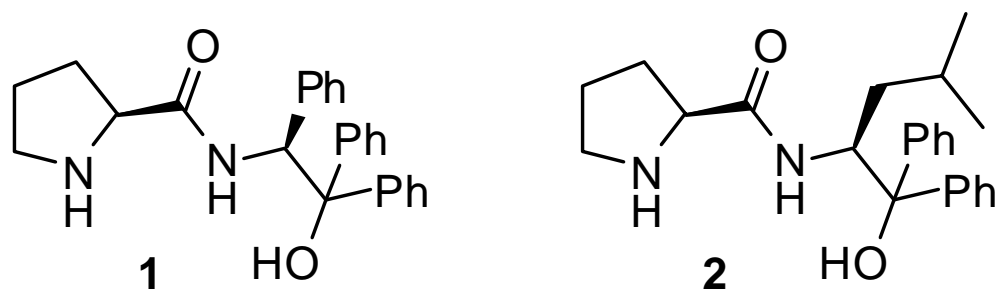

Scheme 1. Structure of catalysts 1 and 2.

In recent years we have been involved in researches aimed to the synthesis and application of recoverable supported proline catalysts. ${ }^{4 \mathrm{a}, 16 \mathrm{a}, 19}$ More recently, we devoted our efforts to the synthesis of $\mathbf{3}$, an immobilized version of catalyst $\mathbf{1}$. $^{20}$

Here, we report the immobilization procedure for catalyst $\mathbf{2}$, in order to demonstrate the wide applicability of our anchoring strategy as well as to test the activity, recoverability and reusability of the catalytic material 4. 


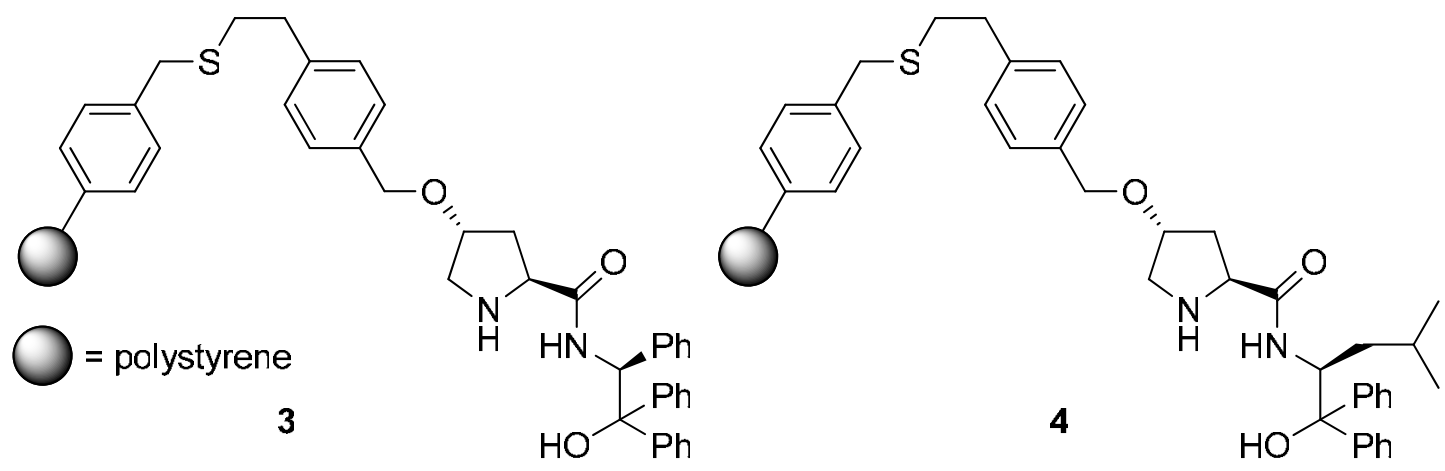

Scheme 2. Structure of supported catalysts 3 and 4.

\section{Results and Discussion}

As first step, we prepared catalyst 4 starting from compound 5, which was easily obtained from 4-vinyl-benzylchloride and 4-hydroxy- $N$-Boc-proline. ${ }^{16 a}$ The carboxylic group of acid 5 was converted into the corresponding amide 7 in good yield by reaction with amino alcohol 6 in the presence of ethylchloroformate. Immobilization was achieved by radical reaction, in the presence of AIBN in refluxing toluene, between amide 7 and a mercaptomethyl cross-linked polystyrene ( $1 \%$ cross-linked with DVB, spherical beads, particle size 100-200 mesh, $2.5 \mathrm{mmol} / \mathrm{g}$ loading). Finally, the obtained material was treated with formic acid in order to remove the Boc group to afford the expected catalytic material 4 (prolinamide loading $c a .0 .324 \mathrm{mmol} / \mathrm{g}$ as determined by weight gain). Resin 4 was charaterized by ${ }^{1} \mathrm{H}-\mathrm{HR}-\mathrm{MAS}$ and ${ }^{1} \mathrm{H}-\mathrm{HR}-\mathrm{MAS}-\mathrm{CPMG}$ NMR spectra (Figure 1). From these spectra it is possible to note the presence of the signals of the prolinamide moiety. 

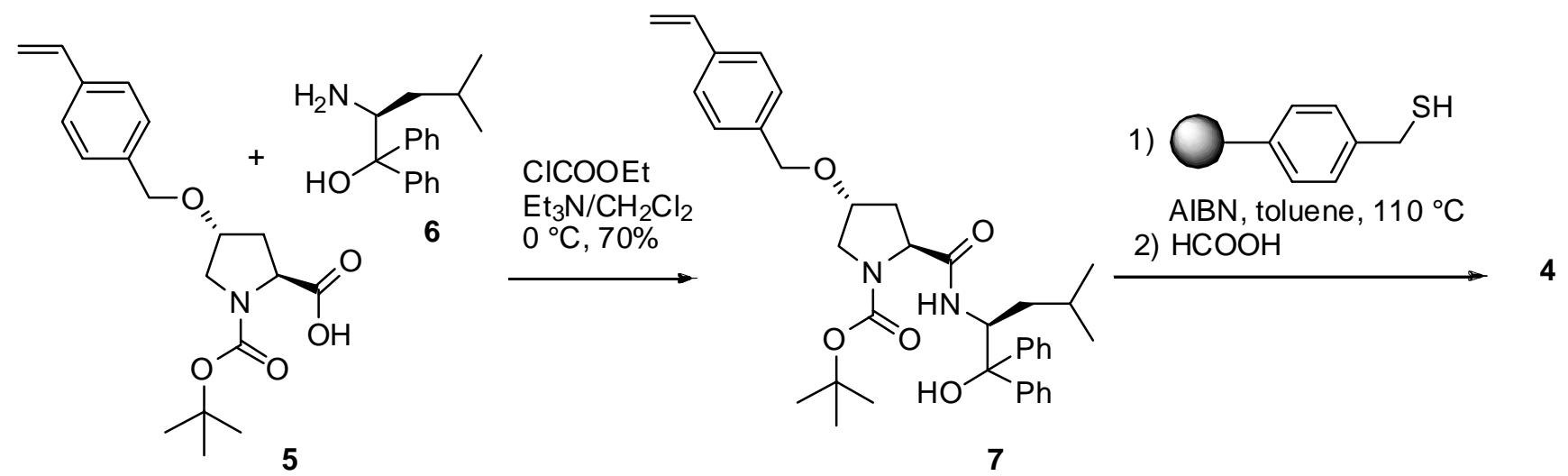

Scheme 3. Synthesis of resin 4.
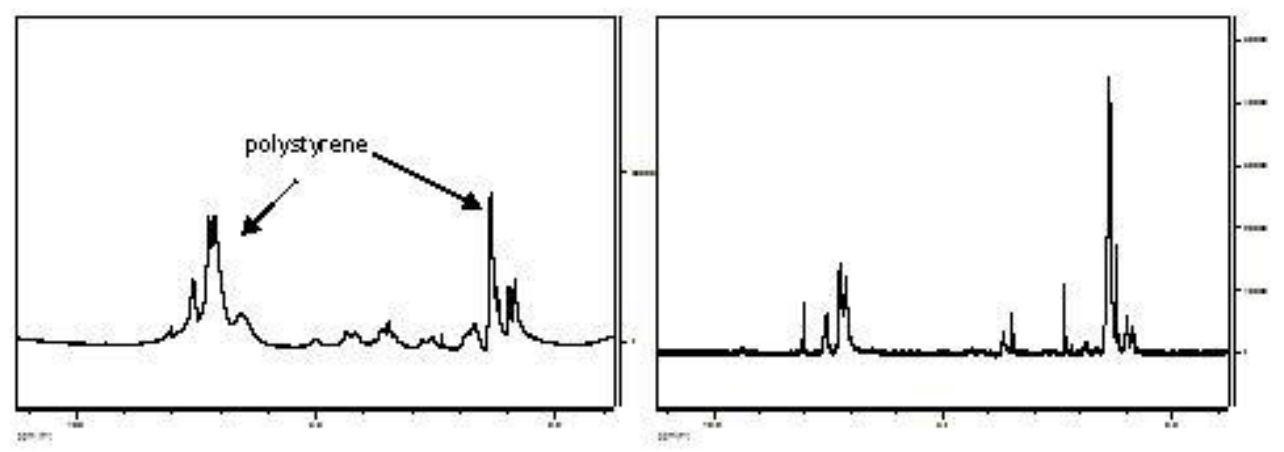

Figure 1. ${ }^{1} \mathrm{H}-\mathrm{HR}-\mathrm{MAS}$ (left) and ${ }^{1} \mathrm{H}-\mathrm{HR}-\mathrm{MAS}-\mathrm{CPMG}$ (right) NMR spectra of resin 4.

We started our investigation using resin 4 in the aldol reaction between acetone and several substituted benzaldehydes (table 1). As a first approach we employed 4-nitro-benzaldehyde. Following our previous results, ${ }^{20}$ we used a water/chloroform mixture as reaction medium. Indeed, resin 4 has a very low surface area $\left(<10 \mathrm{~m}^{2} / \mathrm{g}\right)$, so the above solvent mixture takes advantage of the good swelling properties of chloroform and the ability of water of forming a concentrated organic phase. Reaction gave the aldol product in high yield and excellent enantioselectivity (table 1, entry 1). 
Table 1. Aldol reaction of acetone with substituted benzaldehyde catalyzed by resin 4

\begin{tabular}{|c|c|c|c|c|c|c|c|c|c|}
\hline Entry & $\mathrm{Ar}$ & $\begin{array}{c}\mathrm{H}_{2} \mathrm{O} / \mathrm{CHCl}_{3} \\
(\mu \mathrm{L})\end{array}$ & $\begin{array}{l}\text { Time } \\
\text { (h) }\end{array}$ & Cycle & Reg. ${ }^{a}$ & $\begin{array}{c}\text { Conv. }^{\mathrm{b}} \\
(\%)\end{array}$ & $\begin{array}{c}\text { Yield }^{c} \\
(\%)\end{array}$ & $\mathrm{Ee}^{\mathrm{d}}$ & Conf \\
\hline 1 & $4-\mathrm{NO}_{2}-\mathrm{Ph}$ & $100 / 200$ & 22 & 1 & - & 92 & 89 & 95 & $R$ \\
\hline 2 & $4-\mathrm{NO}_{2}-\mathrm{Ph}$ & $100 / 200$ & 22 & 2 & - & 10 & 6 & 87 & $R$ \\
\hline 3 & $4-\mathrm{NO}_{2}-\mathrm{Ph}$ & $100 / 200$ & 22 & 3 & 1 & 78 & 73 & 94 & $R$ \\
\hline 4 & 4-CN-Ph & $100 / 200$ & 22 & 4 & 2 & 82 & 79 & 96 & $R$ \\
\hline 5 & 2-Cl-Ph & $200 / 200$ & 69 & 5 & 3 & 99 & 98 & 89 & $R$ \\
\hline 6 & $4-\mathrm{CF}_{3}-\mathrm{Ph}$ & $200 / 200$ & 24 & 6 & 4 & 85 & 73 & 95 & $R$ \\
\hline 7 & 2-Cl-5- $\mathrm{NO}_{2}-\mathrm{Ph}$ & $200 / 200$ & 22 & 7 & 5 & $>99$ & 97 & 96 & $R$ \\
\hline 8 & $\mathrm{Ph}$ & $200 / 200$ & 93 & 8 & 6 & 50 & 46 & 88 & $R$ \\
\hline 9 & 2-CN-Ph & $200 / 200$ & 24 & 9 & 7 & $>99$ & 99 & 90 & $R$ \\
\hline 10 & 3-MeO-Ph & $200 / 200$ & 96 & 10 & 8 & 54 & 48 & 88 & $R$ \\
\hline 11 & 2-Cl-6- $\mathrm{NO}_{2}-\mathrm{Ph}$ & $200 / 200$ & 24 & 11 & 9 & $>99$ & 98 & 96 & $R$ \\
\hline 12 & 3-Cl-Ph & 200/200 & 48 & 12 & 10 & 81 & 75 & 90 & $R$ \\
\hline 13 & 4-Cl-Ph & $200 / 200$ & 72 & 13 & 11 & 60 & 53 & 88 & $R$ \\
\hline 14 & 4-Br-Ph & $200 / 200$ & 72 & 14 & 12 & 76 & 63 & 84 & $R$ \\
\hline 15 & 2-naphthyl & $200 / 200$ & 94 & 15 & 13 & 17 & 14 & 86 & $R$ \\
\hline 16 & $4-\mathrm{NO}_{2}-\mathrm{Ph}$ & $200 / 200$ & 22 & 16 & 14 & 99 & 96 & 94 & $R$ \\
\hline
\end{tabular}

${ }^{a}$ Regeneration with formic acid during $2.5 \mathrm{~h}$.

${ }^{\mathrm{b}}$ Determined by ${ }^{1} \mathrm{H}$ NMR of the crude product.

${ }^{\mathrm{c}}$ Isolated yield.

${ }^{\mathrm{d}}$ Determined by HPLC using a chiral stationary phase.

Resin 4 was recovered by filtration and reused in the next cycle. A dramatic drop in activity was observed (table 1, entry 2). The low activity of used resin 4 was ascribed to the formation of the corresponding imidazolidinone (Scheme 4). In order to regenerate resin 4 a treatment with formic acid was carried out. A new cycle was then carried out using again 4-nitro-benzaldehyde (table 1, entry 3). 

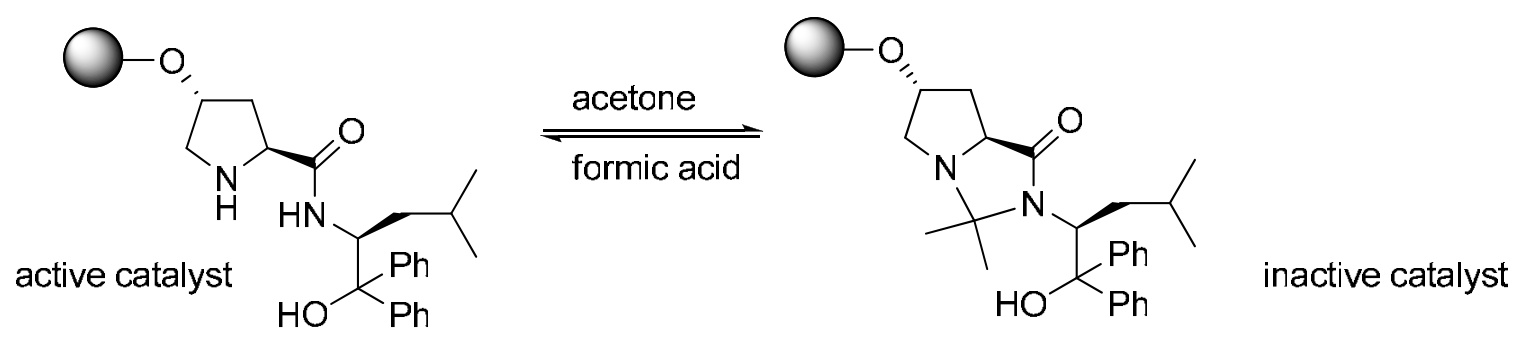

Scheme 4. Inactivation and reactivation of resin 4.

Remarkably, activity and enantioselectivity were restored. In the next cycle a different aldehyde was used, good yield and excellent enantioselectivity were obtained. We reasoned that yields may be increased if a good contact between resin 4 and reagents is realized. To do this, the amount of water was increased. Good to excellent yields were obtained. Yields were lower when less reactive aldehydes were employed. Enantioselectivities were good and in some cases high. Moreover, it is worthy to note that these reactions were carried out using the same recovered and regenerated catalyst. In the case of 2-naphthaldehyde (table 1, entry 15) we found a low conversion. In order to test if this result should be ascribed to a diminished activity of resin $\mathbf{4}$, we repeated the reaction of the first cycle. We found that catalyst 4 was still working with the same efficiency after 16 cycles.

Table 2. Aldol reaction of cyclohexanone with substituted benzaldehyde catalyzed by resin 4

\begin{tabular}{|c|c|c|c|c|c|c|c|c|c|}
\hline & & 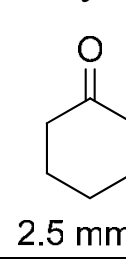 & $\begin{array}{r}\mathrm{O} \\
+\quad 11\end{array}$ & $\mathrm{Ar}$ & $\begin{array}{c}\mathbf{4} \\
(10 \mathrm{~mol}-\%) \\
\mathrm{H}_{2} \mathrm{O} / \mathrm{CHCl}_{3} \\
\begin{array}{c}00 / 200 \mu \mathrm{L} \\
\text { rt }\end{array}\end{array}$ & & ${ }^{\mathrm{OH}}$ & & \\
\hline Entry & $\mathrm{Ar}$ & $\begin{array}{l}\text { Time } \\
(\mathrm{h})\end{array}$ & Cycle & Reg. ${ }^{\text {a }}$ & $\begin{array}{c}\text { Conv. } \\
(\%)\end{array}$ & $\begin{array}{c}\text { Yield }^{\mathrm{c}} \\
(\%)\end{array}$ & Anti/syn ${ }^{b}$ & $\mathrm{Ee}^{\mathrm{d}}$ & Conf. \\
\hline 1 & $4-\mathrm{NO}_{2}-\mathrm{Ph}$ & 22 & 17 & 15 & 98 & 95 & $98 / 2$ & 98 & $2 S, 1^{\prime} R$ \\
\hline 2 & 3-Cl-Ph & 72 & 18 & 16 & 75 & 71 & $97.5 / 2.5$ & 94 & $2 S, 1^{\prime} R$ \\
\hline 3 & 4-CN-Ph & 22 & 19 & 17 & 87 & 84 & $91 / 9$ & 98 & $2 S, 1^{\prime} R$ \\
\hline 4 & $4-\mathrm{CF}_{3}-\mathrm{Ph}$ & 48 & 20 & 18 & 85 & 82 & $98 / 2$ & 80 & $2 S, 1^{\prime} R$ \\
\hline 5 & 3-MeO-Ph & 96 & 21 & 19 & 35 & 31 & $97 / 3$ & 94 & $2 S, 1^{\prime} R$ \\
\hline 6 & $3-\mathrm{NO}_{2}-\mathrm{Ph}$ & 48 & 22 & 20 & 71 & 67 & $97 / 3$ & 80 & $2 S, 1^{\prime} R$ \\
\hline
\end{tabular}

${ }^{\mathrm{a}}$ Regeneration with formic acid during $2.5 \mathrm{~h}$.

${ }^{b}$ Determined by ${ }^{1} \mathrm{H}$ NMR of the crude product.

${ }^{\mathrm{c}}$ Isolated yield.

${ }^{\mathrm{d}}$ Determined by HPLC using a chiral stationary phase. 
Then we used the same catalyst in the reaction between cyclohexanone and several substituted benzaldehydes (table 2). We found excellent results except in the case of 4-CF 3 and 3- $\mathrm{NO}_{2}$-benzaldehydes which gave lower e.e. values. A comparison with the results obtained using catalyst $3^{20}$ showed that catalyst 4 gave comparable or slightly less good stereoselectivity, however it should be reminded that resin 4 was used up to 22 cycles.

In conclusion we have developed a highly recoverable and regenerable supported organocatalyst for the aldol reaction between ketones and substituted benzaldehydes. Remarkably, our catalytic system showed high stereoselectivities at room temperature while prolinamide 2 was used at -5 or $-10{ }^{\circ} \mathrm{C}$. ${ }^{18 b}$ As observed under homogeneous conditions for catalysts 1 and 2, also resins 3 and $\mathbf{4}$ gave aldol products having the same configuration. Further efforts will be devoted in the future in order to prepare more active and reusable organocatalysts.

\section{Experimental Section}

General Procedures. NMR spectra were recorded with a Bruker $300 \mathrm{MHz}$ spectrometer in $\mathrm{CDCl}_{3}$ as solvent. Solid-state ${ }^{1} \mathrm{H}$ MAS NMR spectra were recorded with a Bruker AV 400, 400 $\mathrm{MHz}$ spectrometer with samples packed in zirconia rotors spinning at $5 \mathrm{kHz}$. FTIR spectra were recorded with a Shimadzu FTIR 8300 infrared spectrophotometer. Carbon and nitrogen contents were determined by combustion analysis in a Fisons EA 1108 elemental analyzer. Optical rotations were measured in chloroform with a Jasco P1010 polarimeter. Chiral HPLC analyses were performed with a Shimadzu LC-10AD apparatus equipped with a SPD-M10A UV detector and Daicel columns (OD-H, AD-H, AS-H, $4.6 \mathrm{~mm}$ x $250 \mathrm{~mm}$ ) with hexane/isopropyl alcohol as eluent. Aldol products are known compounds and showed spectroscopic and analytical data in agreement with their structures. ${ }^{20}$ Anti/syn ratio were determined by ${ }^{1} \mathrm{H}$ NMR spectra of the crude reaction mixtures. E.e. values were determined by HPLC chromatograms of the crude reaction mixtures. ${ }^{20}$

\section{(2S,4R)-1-(tert-Butoxycarbonyl)-2-((S)-1-i-butyl-2-hydroxy-2,2-diphenylethyl)-4-(4-vinyl} benzyloxy) pyrrolidine-2-carboxamide (7). Triethylamine (344 $\mu \mathrm{L}, 2.44 \mathrm{mmol})$ was slowly added to a solution of acid $5(0.85 \mathrm{~g}, 2.44 \mathrm{mmol})$ in $\mathrm{CH}_{2} \mathrm{Cl}_{2}(9 \mathrm{~mL})$ at $0{ }^{\circ} \mathrm{C}$. Ethyl chloroformate $(238 \mu \mathrm{L}, 2.44 \mathrm{mmol})$ was added dropwise and the solution was stirred at the same temperature for 15 minutes. Then, amino alcohol $6(0.578 \mathrm{~g}, 2.10 \mathrm{mmol})$ was added and the resulting solution was stirred for $5 \mathrm{~h}$. The solution was diluted with some $\mathrm{CH}_{2} \mathrm{Cl}_{2}$. After filtration, the solvent was removed under reduced pressure and the residue was purified by column chromatography (petroleum ether/ethyl acetate 5/1-2/1). Yield 70\%, m.p. $179-182{ }^{\circ} \mathrm{C} .[\alpha]_{\mathrm{D}}{ }^{28}=-52.3(c=0.79$, $\left.\mathrm{CHCl}_{3}\right) .{ }^{1} \mathrm{H}$ NMR $\left(300 \mathrm{MHz}, \mathrm{CDCl}_{3}\right): \delta=0.76\left(\mathrm{~d}, J=6.3 \mathrm{~Hz}, \mathrm{CH}_{3} \mathrm{CH}\right), 0.86(\mathrm{~d}, J=6.2 \mathrm{~Hz}$, $\left.\mathrm{CH}_{3} \mathrm{CH}\right), 1.31$ (s, tert-butyl), 1.05-1.40 (m, 2H), 1.50-2.00 (m, 3H), 3.20-3.40 (m, 1H), 3.50-3.60 $(\mathrm{m}, 3 \mathrm{H}, \mathrm{OH}), 3.95-4.40(\mathrm{~m}, 4 \mathrm{H}), 5.16\left(\mathrm{~d}, J=10.9 \mathrm{~Hz}, \mathrm{CH}=\mathrm{CH}_{2}\right), 5.65(\mathrm{~d}, J=17.5 \mathrm{~Hz}$, $\left.\mathrm{CH}=\mathrm{CH}_{2}\right), 6.62\left(\mathrm{dd}, J=17.5\right.$ and $\left.10.9 \mathrm{~Hz}, \mathrm{CH}=\mathrm{CH}_{2}\right), 7.02-7.33(\mathrm{~m}, 10 \mathrm{H}, \mathrm{ArH})$. 7.41-7.46 (m, 
4H, ArH). IR (nujol) v 3329, 1735, $1690 \mathrm{~cm}^{-1}$. Anal. calcd. for $\mathrm{C}_{37} \mathrm{H}_{46} \mathrm{~N}_{2} \mathrm{O}_{5}: \mathrm{C} 74.22, \mathrm{H} 7.74, \mathrm{~N}$ 4.68; found $\mathrm{C} 74.61, \mathrm{H} 7.78, \mathrm{~N} 4.59 .{ }^{13} \mathrm{C} \mathrm{NMR}\left(\mathrm{CDCl}_{3}\right.$ two rotamers):

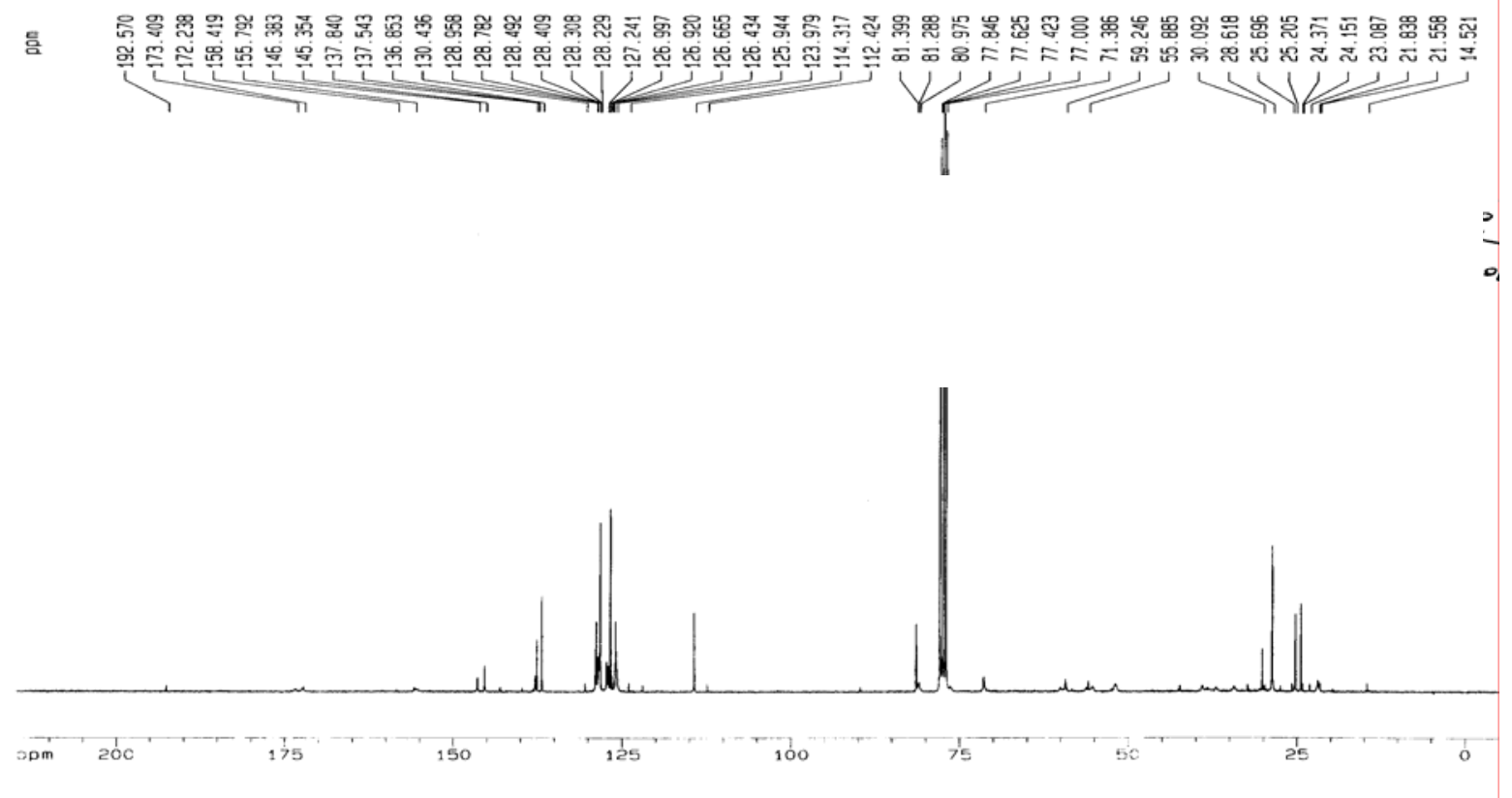

\section{Polystyrene-supported L-prolinamide (4)}

Mercaptomethyl polystyrene $(180 \mathrm{mg}, 0.447 \mathrm{mmol})$ was added to a degassed solution of compound 7 (0.804 g, $1.34 \mathrm{mmol})$ and AIBN (5 mg, $0.027 \mathrm{mmol})$ in toluene $(13 \mathrm{~mL})$. The mixture was stirred at $110^{\circ} \mathrm{C}$ overnight under argon. After cooling to r.t. the resin was filtered and washed with dichloromethane. A yellow resin was obtained $(255 \mathrm{mg}$ ). From the weight increase it was calculated that $0.125 \mathrm{mmol}$ of monomer has been covalently attached to the resin. The dichloromethane solution was evaporated under reduced pressure in order to recover the unreacted prolinamide 7 which was then purified by column chromatography (recovery 90\%). The resin was suspended in $\mathrm{HCOOH}(1 \mathrm{~mL})$ and stirred for $20 \mathrm{~h}$. After this time, water was added and the mixture was filtered. The resin was washed with a saturated solution of $\mathrm{NaHCO}_{3}$, water, methanol and diethyl ether. The resin was dried in oven at $60{ }^{\circ} \mathrm{C}$ for several minutes $(247$ $\mathrm{mg}$ ). The weight difference corresponds to the amount of Boc removed, which is identical to the amount of available proline $\left(0.08 \mathrm{mmol} / 0.247 \mathrm{~g}=0.324 \mathrm{mmol} \mathrm{g}^{-1}\right)$.

\section{Typical procedure for aldol reaction}

Catalyst 4 was added $(0.05 \mathrm{mmol})$ to a mixture of the corresponding aldehyde $(0.5 \mathrm{mmol})$ and ketone $(2.5 \mathrm{mmol})$ in distilled water $(0.10 \mathrm{~mL})$ and chloroform $(0.20 \mathrm{~mL})$ and the reaction mixture was stirred at r.t. The reaction mixture was filtered, the catalyst was washed thoroughly with methanol, ethyl acetate and diethyl ether. The organic layers were collected and, after evaporation of solvent, the crude product was checked by ${ }^{1} \mathrm{H}$ NMR spectroscopy and HPLC, and was then purified by chromatography (petroleum ether/ethyl acetate). 


\section{Procedure for catalyst regeneration}

The recovered catalyst was placed in a round bottom flask and $\mathrm{HCOOH}$ was added (usually $200 \mu \mathrm{L}$ for $100 \mathrm{mg}$ of catalyst). The mixture was agitated for $2.5 \mathrm{~h}$, then filtered and washed with water, aqueous $\mathrm{NaHCO}_{3}$, water, $\mathrm{MeOH}$ and diethyl ether. Finally, it was dried for a few minutes at $60{ }^{\circ} \mathrm{C}$.

\section{Acknowledgements}

Financial support from the University of Palermo (Funds for selected topics) and Italian MIUR within the National Project "Catalizzatori, metodologie e processi innovativi per il regio- $e$ stereocontrollo delle sintesi organiche" and the "Centro Grandi Apparecchiature - UniNetLab Università di Palermo funded by P.O.R. Sicilia 2000-2006, Misura 3.15 Quota Regionale" ( ${ }^{1} \mathrm{H}-$ HR-MAS and ${ }^{1}$ H-HR-MAS-CPMG NMR spectra) are gratefully acknowledged.

\section{References and Notes}

1. (a) Berkessel, A.; Gröger, H. Asymmetric Organocatalysis: From Biomimetic Concepts to Applications in Asymmetric Synthesis, Wiley-VCH: Weinheim, 2005. (b) Dalko, P. I. Enantioselective Organocatalysis, Wiley-VCH: Weinheim, 2007. (c) Special issue on organocatalysis: Chem. Rev. 2007, 107, 5413. (d) Special issue on organocatalysis: Acc. Chem. Res. 2004, 37, 631. (e) Special issue on organocatalysis: Adv. Synth. Catal. 2004, 346, 1007. (f) Special issue on organocatalysis: Tetrahedron 2006, 62, 243.

2. (a) Gruttadauria, M.; Giacalone, F.; Noto, R. Chem. Soc. Rev. 2008, 37, 1666. (b) Cozzi, F. Adv. Synth. Catal. 2006, 348, 1367. (c) Benaglia, M.; Puglisi, A.; Cozzi, F. Chem. Rev. 2003, 103, 3401. (d) Corma, A.; Garcia, H. Adv. Synth. Catal. 2006, 348, 1391. (e) Benaglia, M. New. J. Chem. 2006, 30, 1525. (f) De Vos, D. E.; Vankelecom, I.; Jacobs, P. A. Chiral Catalyst Immobilization and Recycling, Wiley-VCH: Weinheim, 2000.

3. (a) Benaglia, M.; Cinquini, M.; Cozzi, F.; Pugliesi, A.; Celentano, G. Adv. Synth. Catal. 2002, 344, 533. (b) Chandrasekhar, S.; Ramakrishna Reddy, N.; Shameen Sultana, S.; Narsihmulu, Ch.; Venkatram Reddy, K. Tetrahedron 2006, 62, 338. (c) Wu, Y.; Zhang, Y.; Yu, M.; Zhao, G.; Wang, S. Org. Lett. 2006, 8, 4417.

4. (a) Giacalone, F.; Gruttadauria, M.; Mossuto Marculescu, A.; Noto, R. Tetrahedron Lett. 2007, 48, 255. (b) Doyagüez, E. G.; Calderón, F.; Fernández, R.; Sánchez, F.; FernándezMayoralas, A. J. Org. Chem. 2007, 72, 9353. (c) Chouhan, G.; Wang, D.; Alper, H. Chem. Commun. 2007, 4809. 
5. Aprile, C.; Giacalone, F.; Gruttadauria, M.; Mossuto Marculescu, A.; Noto, R.; Revell, J. D.; Wennemers, H. Green Chem. 2007, 9, 1328.

6. Kucherenko, A. S.; Struchkova, M. I.; Zlotin, S. G. Eur. J. Org. Chem. 2006, 2000.

7. Shen, Z.; Ma, J.; Liu, Y.; Jiao, C.; Li, M.; Zhang, Y. Chirality 2005, 17, 556.

8. (a) An, Z.; Zhang, W.; Shi, H.; He, J. J. Catal. 2006, 241, 319. (b) Luo, S.; Li, J.; Zhang, L.; Xu, H.; Cheng, J.-P. Chem. Eur. J. 2008, 14, 273.

9. Kotrusz, P.; Kmentová, I.; Gotov, B.; Toma, Š.; Solčaniová, E. Chem. Commun. 2002, 2510.

10. Miao, W.; Chan, T. H. Adv. Synth. Catal. 2006, 348, 1711.

11. Reviews on proline-catalyzed reactions: (a) List, B. Tetrahedron 2002, 58, 5573. (b) Jarvo, E. R.; Miller, S. J. Tetrahedron 2002, 58, 2481. (c) Notz, W.; Tanaka, F.; Barbas III, C. F. Acc. Chem. Res. 2004, 37, 580.

12. (a) Hajos, Z. G.; Parrish, D. R. Ger. Pat. 2102 623, 1971. (b) Hajos, Z. G.; Parrish, D. R. J. Org. Chem. 1974, 39, 1615. (c) Eder, U.; Sauer, G.; Wiechert, R. Ger. Pat. 2014 757, 1971. (d) Eder, U.; Sauer, G.; Wiechert, R. Angew. Chem. Int. Ed. 1971, 10, 496.

13. List, B.; Lerner, R. A.; Barbas III, C. F. J. Am. Chem. Soc. 2000, 122, 2395.

14. Mukherjee, S.; Yang, J. W.; Hoffmann, S.; List, B. Chem. Rev. 2007, 107, 5471.

15. (a) Mase, N.; Nakai, Y.; Ohara, N.; Yoda, H.; Takabe, K.; Tanaka, F.; Barbas III, C. F. J. Am. Chem. Soc. 2006, 128, 734. (b) Hayashi, Y.; Sumiya, T.; Takahashi, J.; Gotoh, H.; Urushima, T.; Shoji, M. Angew. Chem. Int. Ed. 2006, 45, 958.

16. (a) Gruttadauria, M.; Giacalone, F.; Mossuto Marculescu, A.; Riela, S.; Noto, R. Eur. J. Org. Chem. 2007, 4688. (b) Font, D.; Sayalero, S.; Bastero, A.; Jimeno, C.; Pericás, M. A. Org. Lett. 2008, 10, 337.

17. (a) Raj, M.; Maya, V.; Ginotra, S. K.; Singh, V. K. Org. Lett. 2006, 8, 4097. (b) Tang, Z.; Jiang, F.; Yu, L. T.; Cui, X.; Gong, L. Z.; Mi, A. Q.; Jiang, Y. Z.; Wu, Y. D. J. Am. Chem. Soc. 2003, 125, 5262. (c) Tang, Z.; Jiang, F.; Cui, F.; Gong, L. Z.; Mi, A. Q.; Jiang, Y. Z.; Wu, Y. D. Proc. Natl. Acad. Sci. U.S.A. 2004, 101, 5755. (d) Tang, Z.; Yang, Z. H.; Chen, X. H.; Cun, L. F.; Mi, A. Q.; Jiang, Y. Z.; Gong, L. Z. J. Am. Chem. Soc. 2005, 127, 9285. (e) Guillena, G.; Hita, M.; Nájera, C. ARKIVOC 2007, 260.

18. (a) Zhao, J.-F.; He, L.; Jiang, J.; Tang, Z.; Cun, L.-F.; Gong, L.-Z. Tetrahedron Lett. 2008, 49, 3372. (b) Maya, V.; Raj, M.; Singh, V. K. Org. Lett. 2007, 9, 2593. (c) Chen, X. H.; Tang, Z.; Luo, S. W.; Cun, L. F.; Mi, A. Q.; Jiang, Y. Z.; Gong, L. Z. Chem. Eur. J. 2007, 13, 689. (d) Zu, L.; Xie, H.; Li, H.; Wang, J.; Wang, W. Org. Lett. 2008, 10, 1211; e) Russo, A.; Botta, G.; Lattanzi, A. Tetrahedron 2007, 63, 11886. (f) Guizzetti, S.; Benaglia, M.; Raimondi, L.; Celentano, G. Org. Lett. 2007, 9, 1247. (g) Wang, C.; Jiang, Y.; Zhang, X.-x.; Huang, Y.; Li, B.-g.; Zhang, G.-1. Tetrahedron Lett. 2007, 48, 4281. (h) Lei, M.; Shi, L.; Li, G.; Chen, S.; Fang, W.; Ge, Z.; Cheng, T.; Li, R. Tetrahedron 2007, 63, 7892. (i) Wu, Y.; Zhang, Y.; Yu, M.; Zhao, G.; Wang, S. Org. Lett. 2006, 8, 4417. (j) Sathapornvajana, S.; Vilaivan, T. Tetrahedron 2007, 63, 10253. (k) Fu, Y.-Q.; Li, Z.-C.; Ding, L.-N.; Tao, J.-C.; Zhang, S.-H.; Tang, M.-S. Tetrahedron: Asymmetry 2006, 17, 3351. (1) Gryko, D.; Saletra, W. J. Org. Biomol. Chem. 2007, 5, 2148. 
19. (a) Giacalone, F.; Gruttadauria, M.; Mossuto Marculescu, A.; D’Anna, F.; Noto, R. Catal. Commun. 2008, 9, 1477. (b) Gruttadauria, M.; Riela, S.; Lo Meo, P.; D’Anna, F.; Noto, R. Tetrahedron Lett. 2004, 45, 6113. (c) Gruttadauria, M.; Riela, S.; Aprile, C.; Lo Meo, P.; D’Anna, F.; Noto, R. Adv. Synth. Catal. 2006, 348, 82.

20. Gruttadauria, M.; Giacalone, F.; Mossuto Marculescu, A.; Noto, R. Adv. Synth. Catal. 2008, 350, 1397. 